Sitzungsberichte der Akademie der Wissenschaften der DDR

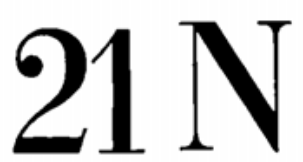

Mathematik - Naturwissenschaften - Technik

1980

\title{
Aus der Arbeit der
}

Forschungsbereiche

der AdW der DDR

Festkolloquium zum 70.Geburtstag des Präsidenten Hermann Klare 
